\title{
Evaluation of In Vivo Antidiarrheal Activity of Solvent Fractions of Hagenia abyssinica (Rosaceae) in Swiss Albino Mice
}

\author{
Zemene Demelash Kifle ${ }^{D},{ }^{1}$ Birhanu Berihun Kidanu, ${ }^{2}$ Tesfaye Yimer Tadesse, ${ }^{3}$ \\ Teshome Fentik Belachew, ${ }^{4}$ and Seyfe Asrade Atnafie $\mathbb{1}^{1}$ \\ ${ }^{1}$ University of Gondar, College of Medicine and Health Sciences, School of Pharmacy, Department of Pharmacology, \\ Gondar, Ethiopia \\ ${ }^{2}$ University of Gondar, College of Veterinary Medicine and Animal Sciences, Department of Veterinary Pharmacy, \\ Gondar, Ethiopia \\ ${ }^{3}$ Debretabor University, College of Health Science, Department of Pharmacy, Debre Tabor, Ethiopia \\ ${ }^{4}$ Department of Pharmacy, Debre Birhan Health Science College, Debre Birhan, Ethiopia
}

Correspondence should be addressed to Zemene Demelash Kifle; zeme2010@gmail.com

Received 10 August 2020; Revised 3 February 2021; Accepted 4 February 2021; Published 13 February 2021

Academic Editor: Muhammad Nabeel Ghayur

Copyright $@ 2021$ Zemene Demelash Kifle et al. This is an open access article distributed under the Creative Commons Attribution License, which permits unrestricted use, distribution, and reproduction in any medium, provided the original work is properly cited.

\begin{abstract}
Background. Ethiopia has several medicinal plants that have been used for their antidiarrheal activity. Hagenia abyssinica is the most commonly used medicinal plant for the management of diarrhea in Ethiopia. Thus, this study's aim is to investigate the antidiarrheal effect of solvent fractions of $H$. abyssinica. Methods. Antidiarrheal activity of extract fractions obtained from different solvents was evaluated by using small intestine transit, enteropooling, and castor oil-induced diarrhea animal models. In all animal models, the solvent fractions treated groups were treated with three different doses ( $100 \mathrm{mg} / \mathrm{kg}, 200 \mathrm{mg} / \mathrm{kg}$, and $400 \mathrm{mg} / \mathrm{kg})$ of the solvent fractions, while the negative control group was treated with a vehicle (distilled water), and positive control group was treated with loperamide. Results. The acute toxicity test revealed that the $\mathrm{LD}_{50}$ of $\mathrm{H}$. abyssinica is $>2000 \mathrm{mg} / \mathrm{kg}$. In castor oilinduced, the solvent fractions of $H$. abyssinica (at $200 \mathrm{mg} / \mathrm{kg}$ and $400 \mathrm{mg} / \mathrm{kg}$ ) significantly $(P<0.05-0.001)$ prolonged the stool frequency, reduced the weight of feces, and delayed diarrheal onset time as compared with the negative control group. The fractions produced a significant $(P<0.05)$ antimotility effect at the doses of $200 \mathrm{mg} / \mathrm{kg}$ and $400 \mathrm{mg} / \mathrm{kg}$ as compared to the negative control. All solvent fractions at the middle and higher doses showed a statistically significant dose-dependent reduction in the volume of intestinal contents and weight of the feces. However, the solvent fractions of H. abyssinica at a dose of $100 \mathrm{mg} / \mathrm{kg}$ failed to produce a statistically significant activity in all parameters (number of wet feces, the onset of diarrhea, and number of total feces) when compared with the negative control group. Conclusion. The extract fractions obtained from different solvents have shown significant antidiarrheal activity. Thus, this finding supports the claimed traditional use of $H$. abyssinica leaves for the treatment of diarrhea.
\end{abstract}

\section{Introduction}

Diarrhea is a condition of increased intestinal emptying and increased water content in the stool. Generally, if defecation occurs more than 3 times a day, excretion of fecal with soft/ liquid consistency or a combination of both showed an abnormal condition in the defecation process [1]. Eighty percent of the Ethiopian population have depended on traditional medicine due to insufficient access to modern medicine, acceptability by the community, and low cost of herbal medicine [2].

Several medicinal plants that possess antidiarrheal activity are available throughout the world. The antidiarrheal effects of these herbs could be due to the attendance of phytoconstituents including flavonoids, alkaloids, saponins, terpenoids, steroids, and tannins [3]. Scientific investigation for the search on novel antidiarrheal compounds from medicinal plants like leaf extract of Osyris quadripartite [4], 
leaf extract of Justicia schimperiana [5], leaf extract of Myrtus communis [6], and flower extract of Ixora Coccinea [7] have shown promising results.

H. abysinica is the sole species of the genus Hagenia and belongs to the family Rosaceae [8]. The species is found in different parts of Africa such as Ethiopia, Congo, Tanzania, Uganda, Sudan, Malawi, Burundi, Rwanda, and Kenya [9]. Rosaceae is a large family containing more than 100 genera and 2,000 species of herbs, shrubs, and trees [10]. The bark, flower, leaf, and root parts of $H$. abyssinica have been used for both medical and nonmedical purposes [8]. The ethnobotanical survey revealed that the bark of $H$. abyssinica had been used for the treatment of stomachache, livestock disease, malaria, dermatological conditions, fever, and bronchitis. The flower part of $H$. abyssinica has been used for the management of different diseases such as epilepsy, intestinal worms, evil eye, healing wound, hepatitis, STD's, and biliary disease. The root part of $H$. abyssinica has been used for the treatment of stomachache, cancer, throat disease, and abdominal pain. The leaves of $H$. abyssinica have also been used for the management of cancer, cough, hypertension, livestock disease, bone fracture, wound, and diarrhea $[11,12]$. In Ethiopia, the leaf part of $H$. abyssinica has been used for the management of the diarrheal disease $[11,13,14]$. Therefore, this study aims to evaluate the in vivo antidiarrheal effect of the leaf's solvent fractions of $H$. abyssinica.

\section{Materials and Methods}

2.1. Drugs, Reagents, and Instruments. Activated charcoal (Acura Organics Ltd, New Delhi), loperamide hydrochloride (Brawn Laboratories Ltd, India), castor oil (API, Jordan), Methanol (Blulux, India), ethyl acetate (Blulux laboratories ltd, India), chloroform (Finkem Laboratory Reagent, India), glacial acetic acid, sulfuric acid, ammonia, hydrochloric acid and ferric chloride (BDH Laboratory Supplies Poole, England), benzene (Fisher Scientific, UK), acetic anhydride, ethyl acetate, digital electronic balance (EPH-400 Abron Exports), microhematocrit centrifuge (Medit-Medizin Technik, Germany), Vacuum freeze dryer (Lab freeze group, digital thermometer (Infiniti Medlab Pvt, Ltd., India), Hot air oven (Medit-Medizin Technik, Germany), Germany), qualitative Whatman filters paper No.1, and oral feeding tube were used in this experiment.

2.2. Plant Materials. The leaves of $H$. abyssinica were harvested in the Northwest part of Ethiopia, Amhara region of Kosoye, on February 12, 2019. Then the collected leaves of $H$. abyssinica were washed using distilled water and dried at room temperature. The identification and authentication of the leaves of $H$. abyssinica were done by a botanist, and the voucher specimens (003ZDK/2019) were placed at the Department of Biology, University of Gondar, Ethiopia.

2.3. Extraction and Fractionation. The leaves of $H$. abyssinica were washed with distilled water to remove dirt and dust, and the cleaned plant materials were dried at room temperature $\left(25-27^{\circ} \mathrm{C}\right)$. The plant materials were grounded into a coarse powder with an electrical mill. Therefore, the fine powder plant materials were macerated separately in methanol for roughly 72 hours, and then the plant materials were filtered using Whatman filter paper No. 1. Likewise, a fresh solvent was used to remacerate the marc, filtrates of each successive maceration were concentrated using a rotary evaporator. Lastly, the semidried residues were frozen in a refrigerator and dried using a lyophilizer (Labfreez, China) to entirely confiscate the remaining solvent $[15,16]$. Water, ethyl acetate, and chloroform solvents were used for fractionation of the crude extract of $H$. abyssinica. Distilled water was briefly added to the crude extract of $H$. abyssinica and dissolved by using a separating funnel. Chloroform was then added and shaken to dissolve the components. Similarly, on the aqueous layer, an equal volume of ethyl acetate was added to it. In both cases, two layers were separated. The subsequent chloroform and ethyl acetate layers were separated and exposed to evaporation by using a hot air oven $\left(40^{\circ} \mathrm{C}\right)$. Then, the dried solvent fractions of $H$. abyssinica were kept separately in a desiccator until being used for the experiment [17].

2.4. Preliminary Phytochemical Screening of Leaves Solvent Fractions. Qualitative tests were done for the solvent fractions of $H$. abyssinica for the presence of phytoconstituents such as steroidal compounds, saponins, terpenes, flavonoids, tannins, alkaloids, and phenolic compounds, by procedures as described in Trease and Evans, 1989 [18].

2.5. Acute Oral Toxicity Test. The acute oral toxicity of $H$. abysinica was conducted according to the Organization for Economic Cooperation and Development (OECD) guideline No. 425 [19]. On the first day of the test, one female Swiss albino mice fasted for $4 \mathrm{hrs}$. Then, $2000 \mathrm{mg} / \mathrm{kg}$ of the extract was administered by oral route using oral gavage. The mice were observed for the manifestation of behavioral and physical changes, and special attention was given during the first four hours. Depending on the results from the first mice, the next 4 female mice fasted for an estimated $4 \mathrm{hrs}$ and then a single dose of $2000 \mathrm{mg} / \mathrm{kg}$ of the extract was given orally and followed in the same manner. The observation continued daily for a total of fourteen days [19].

2.6. Experimental Procedures and Designs. Healthy Swiss albino mice of both sexes weighing 25-30 g were used for this experiment. The mice were retained in a plastic mice cage, with the provision of fed or feed with a standard diet and water. The mice were kept beneath a standard temperature, humidity, and 12 hours light and darkness cycle, and all groups of mice were acclimatized for about 2 weeks before the experiment [20]. Throughout the study period, the mice were assigned into three groups, a positive control group, a negative control group, and a test group containing six mice per group. In all animal models, the first negative control groups received distilled water $(10 \mathrm{ml} / \mathrm{kg})$, the $\mathrm{sec}$ ond positive control received loperamide $(3 \mathrm{mg} / \mathrm{kg})$, and the next three groups (II, III, and IV) received different doses 
(100 mg/kg, $200 \mathrm{mg} / \mathrm{kg}$ and $400 \mathrm{mg} / \mathrm{kg}$ ) of $\mathrm{H}$. abyssinica solvent fractions via the oral route. The doses of the solvent fractions of $H$. abyssinica were determined based on the result of the acute oral toxicity test. The middle doses of the solvent fractions of $H$. abyssinica were $1 / 10$ of the limit dose, the higher doses of the solvent fractions were twice of the middle doses of the solvent fractions of $H$. abyssinica, and a half dose of the middle doses of $H$. abyssinica was the lower dose of the solvent fractions of $H$. abyssinica $[19,21]$.

2.7. Castor Oil-Induced Diarrhea Model. Thirty Swiss albino mice of either sex were deprived of food for 18 hours with free access to water and divided randomly into five groups, as mentioned above. After 1 hour of treatment with the vehicle (distilled water), solvent fractions $(100 \mathrm{mg} / \mathrm{kg}$,
$200 \mathrm{mg} / \mathrm{kg}$, and $400 \mathrm{mg} / \mathrm{kg}$ ), and loperamide ( $3 \mathrm{mg} / \mathrm{kg})$, diarrhea was induced by oral administration of $0.5 \mathrm{ml}$ of castor oil to each mouse. Following their administration, the animals were placed individually into metabolic cages in which the floor was lined with transparent paper for the collection of fecal matter. The transparent paper was changed every hour for a total of 4 hours. The mice were then removed from their cages and the weight of feces was obtained by subtracting the weight of filter paper from the weight of feces and filter paper. The onset of diarrhea, the number of wet stools, the total number, and the total weight of fecal output were noted. Finally, the percentage of diarrheal inhibition, as well as the percentage of the weight of total fecal output, was calculated by using the following formulas [22]:

$$
\text { percentage of diarrheal inhibition }=\frac{\text { mean number of wet stools }(\text { control group }- \text { treated group }) \times 100}{\text { mean number of wet stools of the control group }} .
$$

2.8. Castor Oil-Induced Intestinal Transit. Therefore, the experimental mice were fasted for 18 hours and had free access to water. The mice were divided into five groups and treated as described above. After 1 hour of treatment, $0.5 \mathrm{ml}$ of castor oil was administered and $1 \mathrm{ml}$ of $5 \%$ activated charcoal suspension in distilled water was administered orally. The mice were then sacrificed by cervical dislocation 2 hours after castor oil administration. Then, the small intestine was dissected out from pylorus to caecum and placed lengthwise on white paper. Finally, the distance traveled by the charcoal meal and the total length of the intestine was measured and expressed as a peristaltic index [23].

$$
\begin{aligned}
\text { peristalysisindex }(\mathrm{PI}) & =\frac{\text { distance travelled by the charcoal meal }}{\text { total length of small intestine }} \times 100, \\
\% \text { of inhibition } & =\frac{\text { PI of negative control }- \text { PI of drug or extract }}{\text { PI of negative control }} \times 100 .
\end{aligned}
$$

2.9. In Vivo Antidiarrheal Index (ADI). The ADI for the solvent fractions of $H$. abyssinica was calculated by merging three parameters engaged from the abovementioned models. Then, it was articulated based on the following formula [24]:

in vivo antidiarrheal index $(\mathrm{ADI})=\sqrt[3]{\mathrm{Dfreq} \times \mathrm{Gmeq} \times \text { Pfreq }}$.

Dfreq is the delay in defecation time as a percentage of negative control; Pfreq is the reduction in purging frequency in the number of wet stools as a percentage of the negative control; and Gmeq is the gut meal travel reduction as a percentage of negative control).

2.10. Castor Oil-Induced Enteropooling Model. Swiss albino mice were deprived of food for 18 hours while water was allowed ad libitum. Then, the mice were grouped and treated similarly as described above. One hour later, $0.5 \mathrm{ml}$ of castor oil was administered to each animal. The mice were sacrificed by cervical dislocation 1 hour after the administration of castor oil; the small intestine of each animal was isolated and weighed. Then, the intestinal content of all mice was collected by draining it into a graduated tube. After the removal of the intestinal content, the intestine of each mouse was reweighed. The volume of each intestinal content was measured [25]. Then, percent reductions in weight and volume of intestinal content were calculated using the following formulas:

$\%$ of inhibition by using MVIC $=\frac{\text { MVICC }- \text { MVICT }}{\text { MVICC }} \times 100$.

MVICC is the Mean Volume of Intestinal Content of Control Group; MVICT is the Mean Volume of Intestinal Content of Test Group; and MVIC is the Mean Volume of Intestinal Content).

$\%$ of inhibition by using MWIC $=\frac{\text { MWICC }- \text { MWICT }}{\text { MWICC }} \times 100$.

MWICC is the Mean Weight of Intestinal Content of Control Group; MWICT is the Mean Weight of Intestinal 
Content of Test Group; and MWIC is the Mean Weight of Intestinal Content.

2.11. Statistical Analysis. The data obtained from the experiments were expressed as mean \pm standard error of means (SEM). Statistical analysis was done using statistical package for social sciences (SPSS) version 24. Between- and withingroup analyses were carried out by using one-way ANOVA, and subsequently Tukey's multiple comparison tests. Finally, the findings were considered significant when $P$ value $<0.05$.

\section{Results}

3.1. The Percentage Yield of Plant Material Extraction. At the end of the extraction, 153 (14.6\%) grams of dried leaf extract were collected. The yields of the fractions were $47.8 \%, 29.8 \%$, and $17.5 \%$ for the aqueous fraction, ethyl acetate fraction, and chloroform fraction, respectively.

3.2. Preliminary Phytochemical Screening of the Solvent Fractions. The phytochemical screening results obtained from the tests were presented in Table 1.

3.3. Acute Toxicity Test. In acute toxicity study, leaves extract of $H$. abyssinica revealed no mortality at $2000 \mathrm{mg} / \mathrm{kg}$ body weight dose. After administration of the extract, the mice did not show any toxic effects like changes in behavioral activities such as anxiety, polyuria, diarrhea, seizures, and coma. Thus, the leaves extract of $H$. abyssinica at $2000 \mathrm{mg} / \mathrm{kg}$ body weight showed good safety and the $\mathrm{LD}_{50}$ of the H. abysinica extract is $>2000 \mathrm{mg} / \mathrm{kg}$.

3.4. Effects of Solvent Fractions on Castor Oil-Induced Diarrhea. As shown in Table 2, the chloroform solvent fraction and ethyl acetate solvent fraction exhibited a statistically significant reduction in the number of wet feces $(P<0.001$ for both $)$ and the number of total feces $(P<0.05$, $P<0.01$, respectively) at higher doses of the fractions $(400 \mathrm{mg} / \mathrm{kg}$ ) when compared with the negative control group. Similarly, $400 \mathrm{mg} / \mathrm{kg}$ doses of the three fractions significantly $(P<0.001)$ delaying the onset of defecation when compared with the negative control group. However, the chloroform fraction and ethyl acetate solvent fractions failed to exhibit a significant effect in all parameters at $100 \mathrm{mg} / \mathrm{kg}$ and $200 \mathrm{mg} / \mathrm{kg}$ doses as compared to the negative control. Though, the aqueous solvent fraction exhibited a significant effect in all parameters (in the number of wet feces, the onset of diarrhea, and the number of total feces) measured in this model at $200 \mathrm{mg} / \mathrm{kg}$ and $400 \mathrm{mg} / \mathrm{kg}$ doses when compared with the negative control group. The inhibitions of defecation (\%) were $38.46 \%, 57.91 \%$, and $78.00 \%$ by chloroform, ethyl acetate, and aqueous fractions, respectively, at $400 \mathrm{mg} / \mathrm{kg}$ of the solvent fractions (Table 2).

3.5. Effects on Castor Oil-Induced Intestinal Transit in Mice. The middle and high doses of the solvent fractions of $H$. abyssinica (chloroform, ethyl acetate, and aqueous solvent fractions) significantly suppressed the gastrointestinal motility of charcoal when compared with the negative control group. Similarly, the small intestinal transit was significantly $(P<0.001)$ reduced by Loperamide $3 \mathrm{mg} / \mathrm{kg}$ with a percentage value of $67.10 \%$. The reduction of gastrointestinal transit of charcoal (\%) was $7.10 \%, 17.61 \%$, and $31.70 \%$ for the chloroform fraction; $14.00 \%, 35.90 \%$, and $51.92 \%$ for the ethyl acetate fraction; and $30.40 \%, 47.30 \%$, and $58.83 \%$ for aqueous fraction at tested doses of $100 \mathrm{mg} /$ $\mathrm{kg}, 200 \mathrm{mg} / \mathrm{kg}$, and $400 \mathrm{mg} / \mathrm{kg}$, respectively (Table 3).

3.6. Effects on Castor Oil-Induced Enteropooling. In the intestinal fluid accumulation test, the weight and volume of the intestinal contents were significantly reduced by the chloroform and aqueous solvent fractions at the tested doses of $200 \mathrm{mg} / \mathrm{kg} \quad(P<0.01)$ and $400 \mathrm{mg} / \mathrm{kg} \quad(P<0.001)$ when compared with the negative control group. The maximum percentage inhibition of the volume of gastrointestinal contents was detected at $400 \mathrm{mg} / \mathrm{kg}$ such as $40.70 \%$ $(P<0.001), 47.30 \%(P<0.001)$, and $52.60 \%(P<0.001)$ for aqueous solvent fraction, chloroform solvent fraction, and ethyl acetate solvent fraction, respectively. All fractions exhibited a statistically significant percentage reduction in weight of small intestine with the highest percentage reduction $(40.70 \%, 53.00 \%$, and $47.00 \%$, respectively) at $400 \mathrm{mg} / \mathrm{kg}$ dose of the solvent fractions when compared with the negative control group (Table 4).

3.7. Antidiarrheal Index. The determination of in vivo ADI revealed that the $\mathrm{ADI}$ increased with the dose for each fraction. Among the fractions, an aqueous fraction at its higher tested dose had the maximum ADI as compared to $200 \mathrm{mg} / \mathrm{kg}$ and $400 \mathrm{mg} / \mathrm{kg}$ doses of all fractions, but less than the ADI of Loperamide. The solvent fractions exhibited an ADI of 52.37, 72.17, and 74.14, respectively, for chloroform solvent fraction, ethyl acetate solvent fraction, and aqueous solvent fraction at a dose of $400 \mathrm{mg} / \mathrm{kg}$, respectively, demonstrating a dose-dependent activity on the antidiarrheal index values (Table 5).

\section{Discussion}

Different medicinal plants with antidiarrheal activity have been studied by animal models (effect on gastrointestinal transit, electrolyte, and water secretion) $[26,27]$. The antidiarrheal activity of extract fractions obtained from different solvents of $H$. abyssinica has not been investigated. Therefore, the current study was planned to evaluate the antidiarrheal activity of the solvent fractions of $H$. abyssinica via animal models such as castor oil-induced diarrheal model, antipropulsive, and antientropooling.

Castor oil-induced diarrhea is a commonly used method to evaluate the antidiarrheal activity of medicinal plants [28]. The ricinoleic acid that is released from castor oil through the lipase enzyme stimulates irritation in the gastrointestinal mucosa. This irritation caused secretion of platelet-activating factor, nitric oxide, cyclic adenosine monophosphate, prostaglandin, and tachykinins, which are inflammatory mediators. The 
TAвLE 1: Phytochemical screening of leaves solvent fractions of $H$. abyssinica. (+= Present, - = absent).

\begin{tabular}{lccc}
\hline Metabolites & Ethyl acetate fraction & Chloroform fraction & Aqueous fraction \\
\hline Tannins & + & - & + \\
Alkaloids & - & - & + \\
Saponins & + & + & + \\
Flavonoids & + & + & + \\
Triterpenoid & + & + & - \\
Phenols & + & + & - \\
Steroids & - & - & + \\
Glycosides & + & + & + \\
\hline
\end{tabular}

TABLE 2: Antidiarrheal effects of solvent fractions of $H$. abyssinica.

\begin{tabular}{|c|c|c|c|c|}
\hline Group & Onset of diarrhea ( $\mathrm{min})$ & Number of wet feces & Number of total feces & $\%$ inhibition of defecation \\
\hline Control & $46.83 \pm 3.21$ & $9.10 \pm 0.47$ & $11.83 \pm 0.60$ & - \\
\hline CF $100 \mathrm{mg} / \mathrm{kg}$ & $60.83 \pm 2.12 b^{*}$ & $8.30 \pm 0.34 b^{* * *}$ & $10.00 \pm 0.72 b^{* * *}$ & 8.80 \\
\hline CF $200 \mathrm{mg} / \mathrm{kg}$ & $72.83 \pm 3.38 \mathrm{~b}^{* * *}$ & $7.60 \pm 0.46 b^{* * *}$ & $8.60 \pm 0.46 b^{* * *}$ & 16.50 \\
\hline $\mathrm{CF} 400 \mathrm{mg} / \mathrm{kg}$ & $102 \pm 2.47 \mathrm{a}^{* * *} \mathrm{~b}^{*}$ & $5.60 \pm 0.23 \mathrm{a}^{* * *} \mathrm{~b}^{*}$ & $7.20 \pm 0.20 a^{*} b^{* * *}$ & 38.46 \\
\hline Loperamide $3 \mathrm{mg} / \mathrm{kg}$ & $154.66 \pm 6.8 \mathrm{a}^{* * *}$ & $1.40 \pm 0.2 \mathrm{a}^{* * *}$ & $3.00 \pm 0.25 \mathrm{a}^{* * *}$ & 84.60 \\
\hline Control & $44 \pm 2.84$ & $9.10 \pm 0.47$ & $10.00 \pm 0.85$ & - \\
\hline EAF $100 \mathrm{mg} / \mathrm{kg}$ & $55.5 \pm 2.64 \mathrm{~b}^{* * *}$ & $8.16 \pm 0.77 b^{* * *}$ & $9.00 \pm 0.85 b^{* * *}$ & 10.32 \\
\hline $\mathrm{EAF} 200 \mathrm{mg} / \mathrm{kg}$ & $68.00 \pm 3.65 b^{* * *}$ & $7.10 \pm 0.83 b^{* * *}$ & $7.00 \pm 0.77 \mathrm{~b}^{* * *}$ & 22.20 \\
\hline EAF $400 \mathrm{mg} / \mathrm{kg}$ & $99.00 \pm 4.15 \mathrm{a}^{* * *} \mathrm{~b}^{* * *}$ & $3.83 \pm 0.34 \mathrm{a}^{* * *} \mathrm{~b}^{* * *}$ & $5.33 \pm 0.49 a^{* *} b^{*}$ & 57.91 \\
\hline Loperamide $3 \mathrm{mg} / \mathrm{kg}$ & $141.00 \pm 7.14 \mathrm{a}^{* * *}$ & $1.66 \pm 0.21 \mathrm{a}^{* * *}$ & $3.10 \pm 0.32 \mathrm{a}^{* * *}$ & 76.62 \\
\hline Control & $48.50 \pm 4.52$ & $9.10 \pm 0.47$ & $10.16 \pm 0.75$ & - \\
\hline $\mathrm{AF} 100 \mathrm{mg} / \mathrm{kg}$ & $71.33 \pm 8.76 b^{* * *}$ & $5.16 \pm 0.47 b^{* * *}$ & $6.33 \pm 0.71 b^{* * *}$ & 43.29 \\
\hline AF $200 \mathrm{mg} / \mathrm{kg}$ & $88.65 \pm 7.74 a^{*} b^{* * *}$ & $3.50 \pm 0.42 a^{* *} b^{*}$ & $5.50 \pm 0.61 \mathrm{a}^{* *}$ & 61.53 \\
\hline $\mathrm{AF} 400 \mathrm{mg} / \mathrm{kg}$ & $91.57 \pm 10.88 a^{* *} b^{*}$ & $2.00 \pm 0.25 \mathrm{a}^{* * *}$ & $3.66 \pm 0.33 \mathrm{a}^{* * *}$ & 78.00 \\
\hline Loperamide $3 \mathrm{mg} / \mathrm{kg}$ & $138.50 \pm 7.65 a^{* * *}$ & $1.83 \pm 0.33 a^{* * *}$ & $3.60 \pm 0.18 a^{* * *}$ & 80.00 \\
\hline
\end{tabular}

Data are expressed as mean $\pm \operatorname{SEM}(n=6)$; analysis was performed with One-Way ANOVA followed by Tukey test; ${ }^{\mathrm{a}}$ compared to negative control; ${ }^{\mathrm{b}}$ compared to loperamide $3 \mathrm{mg} / \mathrm{kg} ;{ }^{*} P<0.05,{ }^{* *} P<0.01$, and ${ }^{* * *} P<0.001$; CF: chloroform fraction; EAF: ethyl acetate fraction; AF: aqueous fraction; negative controls received $10 \mathrm{ml} / \mathrm{kg}$ distilled water.

TABLE 3: Effects of solvent fractions on castor oil-induced gastrointestinal motility in mice.

\begin{tabular}{|c|c|c|c|c|}
\hline Dose administered & Length of small intestine $(\mathrm{cm})$ & Distance moved by the charcoal meal $(\mathrm{cm})$ & Peristaltic index $(\%)$ & $\%$ inhibition \\
\hline Control & $58.30 \pm 1.02$ & $46.50 \pm 1.14$ & $84.82 \pm 1.47$ & - \\
\hline $\mathrm{CF} 100 \mathrm{mg} / \mathrm{kg}$ & $58.16 \pm 1.24$ & $46.83 \pm 1.44^{\mathrm{b} * * *}$ & $80.53 \pm 1.67^{\mathrm{b} * * *}$ & 7.10 \\
\hline CF $200 \mathrm{mg} / \mathrm{kg}$ & $57.16 \pm 1.93$ & $40.83 \pm 2.41^{\mathrm{b} * * *}$ & $71.43 \pm 3.14^{\mathrm{a} * \mathrm{~b} * * *}$ & 17.61 \\
\hline $\mathrm{CF} 400 \mathrm{mg} / \mathrm{kg}$ & $56.83 \pm 0.94$ & $33.83 \pm 1.86^{\mathrm{a} * *} \mathrm{~b}_{* * *}$ & $59.50 \pm 3.92^{\mathrm{a} * \mathrm{~b} * * *}$ & 31.70 \\
\hline EA $100 \mathrm{mg} / \mathrm{kg}$ & $55.33 \pm 1.49$ & $41.00 \pm 3.04^{\mathrm{b} * * *}$ & $74.50 \pm 4.72^{\mathrm{a} * \mathrm{~b} * * *}$ & 14.00 \\
\hline EA $200 \mathrm{mg} / \mathrm{kg}$ & $55.83 \pm 1.04$ & $31 \pm 2.61^{\mathrm{b} * * *}$ & $55.54 \pm 4.24^{\mathrm{a} * \mathrm{~b} * * *}$ & 35.90 \\
\hline EA $400 \mathrm{mg} / \mathrm{kg}$ & $56.38 \pm 1.62$ & $23.50 \pm 1.47^{\mathrm{a} * * * \mathrm{~b} * *}$ & $41.68 \pm 2.57^{\mathrm{a} * * * \mathrm{~b} * *}$ & 51.92 \\
\hline AF $100 \mathrm{mg} / \mathrm{kg}$ & $56.60 \pm 1.23$ & $34.16 \pm 1.66^{\mathrm{b} * * *}$ & $60.35 \pm 3.56^{\mathrm{b} * * *}$ & 30.41 \\
\hline AF $200 \mathrm{mg} / \mathrm{kg}$ & $56.16 \pm 0.96$ & $25.66 \pm 2.57^{\mathrm{a} * * * \mathrm{~b} * *}$ & $45.69 \pm 4.22^{\mathrm{a} * * \mathrm{~b} * *}$ & 47.34 \\
\hline AF $400 \mathrm{mg} / \mathrm{kg}$ & $57.00 \pm 1.45$ & $20.33 \pm 1.23^{\mathrm{a} * * * \mathrm{~b} *}$ & $35.66 \pm 3.37^{\mathrm{a} * * * \mathrm{~b} *}$ & 58.83 \\
\hline Loperamide $3 \mathrm{mg} / \mathrm{kg}$ & $55.83 \pm 0.87$ & $18.66 \pm 0.88^{\mathrm{a}^{* * * *}}$ & $33.00 \pm 1.52^{\mathrm{a} * * *}$ & 59.80 \\
\hline
\end{tabular}

Data are expressed as mean \pm SEM $(n=6)$; analysis was performed with One-Way ANOVA followed by Tukey test; ${ }^{\text {a }}$ compared to negative control; ${ }^{\mathrm{b}}$ compared to loperamide $3 \mathrm{mg} / \mathrm{kg} ;{ }^{*} P<0.05,{ }^{* *} P<0.01$, and ${ }^{* * *} P<0.001$; CF: chloroform fraction; EAF: ethyl acetate fraction; AF: aqueous fraction; negative controls received $10 \mathrm{ml} / \mathrm{kg}$ distilled water.

inflammatory mediators stimulate intestinal motility and increase the secretions of water and some electrolyte. Several studies revealed that castor oil could induce diarrhea within one to two hours following administration of $0.1-0.3$ milliliters of castor oil [29, 30].

In the castor oil-induced diarrhea model, the higher doses $(400 \mathrm{mg} / \mathrm{kg})$ of all the solvent fractions exhibited a statistically significant activity in all parameters determined: the number of wet and total stools, the weight of wet stools, and the onset of diarrhea. The extract fractions obtained from different solvents could produce their antidiarrheal effect by antisecretory mechanism as it was apparent from the decrease in the total number of wet feces. Moreover, nonsteroidal anti-inflammatory drugs can inhibit castor oilinduced diarrhea apart from its inhibition of prostaglandin synthesis [31]. Likewise, the extract of $H$. abyssinica has also 
TABLE 4: Effects of solvent fractions on castor oil-induced enteropooling in mice.

\begin{tabular}{|c|c|c|c|c|}
\hline Dose administered & $\begin{array}{l}\text { Mean volume of small } \\
\text { intestinal content (gm) }\end{array}$ & $\%$ inhibition & $\begin{array}{l}\text { Mean weight of small } \\
\text { intestinal content }(\mathrm{ml})\end{array}$ & $\%$ inhibition \\
\hline Control & $0.76 \pm 0.04$ & - & $0.81 \pm 0.01$ & - \\
\hline $\mathrm{CF} 100 \mathrm{mg} / \mathrm{kg}$ & $0.69 \pm 0.02^{\mathrm{b} * * *}$ & 9.20 & $0.69 \pm 0.018^{\mathrm{a} * \mathrm{~b} * * *}$ & 14.80 \\
\hline $\mathrm{CF} 200 \mathrm{mg} / \mathrm{kg}$ & $0.58 \pm 0.02^{\mathrm{a} * * \mathrm{~b} * * *}$ & 23.60 & $0.6 \pm 0.02^{\mathrm{a} * * \mathrm{~b} * * *}$ & 26.00 \\
\hline $\mathrm{CF} 400 \mathrm{mg} / \mathrm{kg}$ & $0.40 \pm 0.04^{\mathrm{a} * * *}$ & 47.30 & $0.48 \pm 0.02^{\mathrm{a} * * *}$ & 40.70 \\
\hline EA $100 \mathrm{mg} / \mathrm{kg}$ & $0.62 \pm 0.21^{\mathrm{a} * \mathrm{~b} * * *}$ & 18.40 & $0.6 \pm 0.02^{\mathrm{a} * * \mathrm{~b} * * *}$ & 26.00 \\
\hline EA $200 \mathrm{mg} / \mathrm{kg}$ & $0.53 \pm 0.09^{\mathrm{a} * * \mathrm{~b} *}$ & 30.20 & $0.51 \pm 0.02^{\mathrm{a} * * * \mathrm{~b} *}$ & 37.00 \\
\hline EA $400 \mathrm{mg} / \mathrm{kg}$ & $0.36 \pm 0.14^{\mathrm{a} * * *}$ & 52.60 & $0.38 \pm 0.01^{\mathrm{a} * * *}$ & 53.00 \\
\hline $\mathrm{AF} 100 \mathrm{mg} / \mathrm{kg}$ & $0.68 \pm 0.018^{\mathrm{b} * * *}$ & 10.50 & $0.71 \pm 0.01^{\mathrm{a} * \mathrm{~b} * * *}$ & 12.30 \\
\hline AF $200 \mathrm{mg} / \mathrm{kg}$ & $0.55 \pm 0.02^{\mathrm{a} * * \mathrm{~b} * * *}$ & 27.60 & $0.59 \pm 0.01^{\mathrm{a} * * \mathrm{~b} * * *}$ & 27.10 \\
\hline $\mathrm{AF} 400 \mathrm{mg} / \mathrm{kg}$ & $0.45 \pm 0.08^{\mathrm{a} * * *}$ & 40.70 & $0.43 \pm 0.02^{\mathrm{a} * * *}$ & 47.00 \\
\hline Loperamide $3 \mathrm{mg} / \mathrm{kg}$ & $0.36 \pm 0.02^{\mathrm{a} * * *}$ & 52.60 & $0.4 \pm 0.01^{\mathrm{a} * * *}$ & 50.60 \\
\hline
\end{tabular}

Data are expressed as mean \pm SEM $(n=6)$; analysis was performed with One-Way ANOVA followed by Tukey test; ${ }^{\mathrm{a}}$ compared to negative control; ${ }^{\mathrm{b}}$ compared to loperamide $3 \mathrm{mg} / \mathrm{kg} ;{ }^{*} P<0.05,{ }^{* *} P<0.01$, and ${ }^{* * *} P<0.001$; CF, chloroform fraction; EAF: ethyl acetate fraction; AF: aqueous fraction; negative controls received $10 \mathrm{ml} / \mathrm{kg}$ distilled water.

TABLE 5: In vivo antidiarrheal index of solvent fractions of H.abyssinica leaves.

\begin{tabular}{|c|c|c|c|c|}
\hline Dose & $\begin{array}{c}\text { Delay in defecation (time of onset in } \\
\text { min, Dfreq) }(\%)\end{array}$ & $\begin{array}{l}\text { Gut meal travel distance } \\
\text { (Gmeq) }(\%)\end{array}$ & $\begin{array}{c}\text { Purging frequency in a number of } \\
\text { wet stools (\%) }\end{array}$ & $\begin{array}{l}\text { In vivo } \\
\mathrm{ADI}\end{array}$ \\
\hline $\mathrm{DW} 10 \mathrm{ml} / \mathrm{kg}$ & - & - & - & - \\
\hline $\mathrm{CF} 100 \mathrm{mg} / \mathrm{kg}$ & 29.89 & 7.10 & 8.80 & 12.31 \\
\hline CF $200 \mathrm{mg} / \mathrm{kg}$ & 55.51 & 17.61 & 16.5 & 25.26 \\
\hline $\mathrm{CF} 400 \mathrm{mg} / \mathrm{kg}$ & 117.80 & 31.7 & 38.46 & 52.37 \\
\hline EAF $100 \mathrm{mg} / \mathrm{kg}$ & 26.13 & 14.00 & 10.32 & 15.57 \\
\hline $\mathrm{EAF} 200 \mathrm{mg} / \mathrm{kg}$ & 54.54 & 35.90 & 22.2 & 35.16 \\
\hline EAF $400 \mathrm{mg} / \mathrm{kg}$ & 125.00 & 51.92 & 57.91 & 72.17 \\
\hline $\mathrm{AF} 100 \mathrm{mg} / \mathrm{kg}$ & 47.07 & 30.40 & 43.29 & 39.54 \\
\hline AF $200 \mathrm{mg} / \mathrm{kg}$ & 82.78 & 47.30 & 61.53 & 62.22 \\
\hline $\mathrm{AF} 400 \mathrm{mg} / \mathrm{kg}$ & 88.80 & 58.83 & 78.00 & 74.14 \\
\hline $\begin{array}{l}\text { Loperamide } \\
3 \mathrm{mg} / \mathrm{kg}\end{array}$ & 185.56 & 59.80 & 82.57 & 97.13 \\
\hline
\end{tabular}

$\mathrm{DW}=$ distilled water, $\mathrm{CF}=$ chloroform fraction, $\mathrm{EAF}=$ ethyl acetate fraction, $\mathrm{AF}=$ aqueous fraction, and $\mathrm{ADI}=$ antidiarrheal index.

revealed anti-inflammatory activities similar to nonsteroidal anti-inflammatory drugs [32]. Therefore, it is reasonable to suppose that the antidiarrheal activity of $H$. abyssinica solvent fractions might be due to a reduction in the production of prostaglandin. The phytoconstituents like terpenoids have been reported to obstruct the synthesis of prostaglandin [33], which are identified to take part in the activation of gastrointestinal secretions [34]. As a result, the significant antidiarrheal activity observed by the extract fractions obtained from different solvents could be because of the occurrence of different phytoconstituents in the solvent fractions of $H$. abyssinica. The current finding is in line with previous similar studies $[4,35,36]$.

The aqueous solvent fraction at its higher dose $(400 \mathrm{mg} /$ $\mathrm{kg}$ ) showed a maximum effect on the percentage inhibition of defecation $(78.00 \%)$. The chloroform fraction, however, was found to be active either at the middle or at the higher dose. The insignificant activity of the solvent fractions at $100 \mathrm{mg} / \mathrm{kg}$ doses could be because of the incapability of the phytoconstituents to reach an adequate amount to elicit antidiarrheal activity. This argument is supported by the fact that activity would be apparent with an increasing dose of the extracts. The current finding is in agreement with previous studies in which the aqueous solvent fractions of numerous medicinal plants have reduced the number of stooling $[4,37]$.

In the gastrointestinal motility model, the most effective and extensively used antidiarrheal drugs produced their effect by different mechanisms such as by reducing the intestinal motility and blocking the secretion of intestinal contents. The activated charcoal model is employed to investigate the activity of medicinal plants on gastrointestinal motility, and it serves as a marker [5]. The higher doses of the solvent fractions of $H$. abyssinica repressed the transit of charcoal meal or propulsive movement throughout the gastrointestinal tract that demonstrates the solvent fractions of $H$. abyssinica leaves could be able to decrease the frequency of stool. However, the lower doses of all tested doses of the solvent fractions and the middle doses of chloroform fraction and ethyl acetate fraction did not show a statistically significant decrement in the percentage of gastrointestinal motility, and this showed that the solvent fractions have less antimotility effect at the lower and the middle doses of the solvent fractions. Cholinergic activation causes diarrhea by 
increasing gastrointestinal motility, while anticholinergics prevent diarrhea by inhibiting cholinergic activation [38]. This finding indicates that the solvent fractions have poor anticholinergic activity on gastrointestinal mucosa at the lower and the middle doses of the solvent fractions. The solvent fractions repressed the propulsion of activated charcoal, which showed the efficacy of the extracts in decreasing the vagal peristaltic movements of the gastrointestinal tract system. These also give details about the muscle relaxant activity of the solvent fractions. This pharmacological effect of the solvent fractions might be one of the more likely mechanisms for their antidiarrheal activities.

In the castor oil-induced enteropooling model, all the solvent fractions of $H$. abyssinica significantly decreased the intraluminal fluid accumulation as compared to the negative control group. The current finding agreed with previous similar studies $[39,40]$. The maximal activity of the solvent fractions was comparable with the standard drug loperamide, which is one of the most commonly used drugs for the treatment of diarrheal disorder [41]; as presented in the current study, loperamide successfully inhibited the induced diarrhea. The ricinoleic acid, which is the metabolite of castor oil, brings inflammation and irritation of the gastrointestinal mucosa, resulting in prostaglandins secretion. The secreted prostaglandins inhibit the reabsorption of water and $\mathrm{NaCl}_{2}$ [42]. Accordingly, the solvent fractions significantly inhibit the gastrointestinal hypersecretion and enteropooling by decreasing gastrointestinal accumulation of fluid or via facilitating reabsorption of water and electrolytes. The antienteropooling effect of the solvent fractions may also be linked to the presence of secondary metabolites such as tannins, steroids, and flavonoids. The phytoconstituents like steroids and flavonoids block the secretion of prostaglandins; by this means, they block the release of prostaglandins and increase the absorption of some electrolytes. Tannins reduce the fluid secretion in the gastrointestinal by different mechanisms such as blocking cystic fibrosis transmembrane conductance regulator and calcium-activated chloride channel, by generating a protein-precipitating reaction to the intestinal mucosa and by free radical scavenging activity [33, 43]. Indeed, it is well established that the liberation of ricinoleic acid from castor oil also causes irritation and inflammation of intestinal mucosa, leading to the release of prostaglandins E2, which results in stimulation of secretion. Similarly, the in vitro and in vivo experiments have shown that flavonoids, terpenoids, and saponins can decrease the gastrointestinal secretion stimulated by prostaglandins, thereby inhibiting secretion activated by castor oil [44].

Several phytoconstituents obtained from different medicinal plants have shown antidiarrheal activity. Among the phytoconstituents, saponins, triterpenoids, and flavonoids have been reported to prevent gastrointestinal motility and electrolyte secretions [45-47].

$H$. abyssinica contains phytoconstituents such as tannins, phenols, flavonoids, saponins, glycosides, alkaloids, anthraquinones, and terpenoids, as tested by phytochemical screening tests. Therefore, the possible antidiarrheal properties of the solvent fractions of $H$. abyssinica might be due to the abovementioned secondary metabolites.

\section{Conclusion}

The findings of the present study demonstrated that the solvent fractions of $H$. abyssinica possessed significant antidiarrheal activities. The antidiarrheal activities of the solvent fractions could probably be attributed to the presence of phytoconstituents in the $H$. abyssinica. Thus, this finding supports the claimed traditional use of $H$. abyssinica leaves for the management of diarrhea.

\section{Data Availability}

The data sets used and/or analyzed during the current study are available from the corresponding author upon reasonable request.

\section{Ethical Approval}

Ethical clearance was obtained from the research and ethics committee of the Department of Pharmacology, University of Gondar, with a Reference number (SOP 04-105-11). Experimental procedures were completed using Swiss albino mice according to the internationally accepted laboratory animal use and care guideline.

\section{Conflicts of Interest}

The authors declare that they have no conflicts of interest.

\section{Acknowledgments}

The authors acknowledge the University of Gondar for material support and for allowing the use of the laboratory facility.

\section{References}

[1] S. Husein, M. Nainggolan, and Y. Y, "Antidiarrheal activity of n-hexane fraction seeds of leucaenae leucocephala (lam) de Wit on rat," Asian Journal of Pharmaceutical Research and Development, vol. 8, no. 2, pp. 10-13, 2020.

[2] K. D. Kassaye et al., "A historical overview of traditional medicine practices and policy in Ethiopia," Ethiopian Journal of Health Development, vol. 20, no. 2, pp. 127-134, 2006.

[3] K. S. Komal and A. Rana, "Herbal approaches for diarrhea: a review," International Research Journal of Pharmacy, vol. 4, no. 1, pp. 31-38, 2013.

[4] M. Y. Teferi, M. Abdulwuhab, and J. S. Yesuf, "Evaluation of in vivo antidiarrheal activity of $80 \%$ methanolic leaf extract of Osyris quadripartita Decne (Santalaceae) in Swiss Albino Mice," Journal of Evidence-Based Integrative Medicine, vol. 24, p. 2515690X19833340, 2019.

[5] B. Mekonnen, A. B. Asrie, and Z. B. Wubneh, "Antidiarrheal activity of $80 \%$ methanolic leaf extract of Justicia schimperiana," Evidence-Based Complementary and Alternative Medicine, vol. 2018, Article ID 3037120, 10 pages, 2018.

[6] M. Sisay, E. Engidawork, and W. Shibeshi, "Evaluation of the antidiarrheal activity of the leaf extracts of Myrtus communis 
Linn (Myrtaceae) in mice model," BMC Complementary and Alternative Medicine, vol. 17, no. 1, p. 103, 2017.

[7] Y. Maniyar, P. Bhixavatimath, and N. Agashikar, "Antidiarrheal activity of flowers of Ixora Coccinea linn. In rats," Journal of Ayurveda and Integrative Medicine, vol. 1, no. 4, p. 287, 2010.

[8] T. Feyissa, "Micropropagation, transformation and genetic diversity of Hagenia abyssinica (Bruce) JF Gmel," vol. 2006, 2006.

[9] H. Beentje, J. Adamson, and D. Bhanderi, Kenya Trees, Shrubs, and Lianas, National Museums of Kenya, Nairobi, Kenya, 1994.

[10] I. Hedberg and S. Edwards, Flora of Ethiopia Pittosporaceae to Araliaceae. Addis Ababa, Ethiopia and Uppsala, Vol. 3, The National Herbarium, Addis Ababa University and Uppsala University, Sweden, 1989.

[11] B. Assefa, G. Glatzel, and C. Buchmann, "Ethnomedicinal uses of Hagenia abyssinica (Bruce) J.F. Gmel. among rural communities of Ethiopia," Journal of Ethnobiology and Ethnomedicine, vol. 6, no. 1, p. 20, 2010.

[12] A. Enyew, Z. Asfaw, E. Kelbessa, and R. Nagappan, "Ethnobotanical study of traditional medicinal plants in and around Fiche District, Central Ethiopia," Current Research Journal of Biological Sciences, vol. 6, no. 4, pp. 154-167, 2014.

[13] L. C. Ngeny et al., "Antimicrobial properties and toxicity of Hagenia abyssinica (bruce) JF gmel, fuerstia africana TCE fries, Asparagus racemosus (willd.) and ekebergia capensis sparrm," African Journal of Pharmacology and Therapeutics, vol. 2, no. 3, 2013.

[14] G. Bekele and P. R. Reddy, "Folklore medicinal uses of Hagenia abyssinica (bruce) JF gmel to treat human ailments by guji oromo tribes in abaya district, borana zone, oromia regional state Ethiopia," International Journal of Physical and Social Sciences, vol. 4, no. 12, pp. 394-408, 2014.

[15] D. Satyajit, Z. L. Sarker, and A. I. Gray, Natural Products Isolation, Biotechnology ${ }^{\mathrm{TM}}$ Humana Press Inc. United Kingdom, UK, Second edition, 2006.

[16] B. Geleta et al., "In vivo antihypertensive and antihyperlipidemic effects of the crude extracts and fractions of Moringa stenopetala (Baker f.) Cufod. leaves in rats," Frontiers in Pharmacology, vol. 7, p. 97, 2016.

[17] M. Molla, N. Gemeda, and S. M. Abay, "Investigating potential modes of actions of Mimusops kummel fruit extract and solvent fractions for their antidiarrheal activities in mice," Evidence-Based Complementary and Alternative Medicine, vol. 2017, Article ID 4103410, 11 pages, 2017.

[18] G. Trease and M. Evans, Text Book of Pharmacognosypp. 200-201, Bailiere Tindall, London, Toronto, 13th edition, 1989.

[19] O. OCDE, "Acute oral toxicity: up and down procedure," OECD. Guideline for the Testing of Chemicals, vol. 425, pp. 1-2, 2008.

[20] G. Ayal, A. Belay, and W. Kahaliw, "Evaluation of wound healing and anti-inflammatory activity of the leaves of Calpurnia aurea (Ait.) Benth (fabaceae) in mice," Wound Medicine, vol. 25, no. 1, p. 100151, 2019.

[21] B. M. Habte et al., "Explanatory models of adult patients with type 2 diabetes mellitus from urban centers of central Ethiopia," BMC Research Notes, vol. 9, no. 1, p. 441, 2016.

[22] M. Mahalakshmi, M. Parimala, and F. Shoba, "Evaluation of anti-diarrhoeal potential of methanol extract of Ficus bengalensis Linn. leaf and Mangifera indica Linn. Stem bark and root bark," International Journal of Pharmacognosy and Phytochemical Research, vol. 6, pp. 454-458, 2014.
[23] A. B. Asrie, M. Abdelwuhab, Z. Shewamene, D. A. Gelayee, G. M. Adinew, and E. Birru, "Antidiarrheal activity of methanolic extract of the root bark of Cordia africana," Journal of Experimental Pharmacology, vol. 8, p. 53, 2016.

[24] E. M. Birru et al., "Antidiarrheal activity of crude methanolic root extract of Idigofera spicata Forssk.(Fabaceae)," BMC Complementary and Alternative Medicine, vol. 16, no. 1, p. 272, 2016.

[25] A. Robert, J. E. Nezamis, C. Lancaster, A. J. Hanchar, and M. S. Klepper, "Enteropooling assay: a test for diarrhea produced by prostaglandins," Prostaglandins, vol. 11, no. 5, pp. 809-828, 1976.

[26] E. A. Palombo, "Phytochemicals from traditional medicinal plants used in the treatment of diarrhoea: modes of action and effects on intestinal function," Phytotherapy Research, vol. 20, no. 9, pp. 717-724, 2006.

[27] V. Chaddha, A. S. Kushwah, and V. Shrivastava, "An importance of herbal drugs as antidiarrheal: a review," International Journal of Research in Applied, Natural and Social Sciences, vol. 1, no. 7, pp. 25-28, 2013.

[28] A. Degu, "Evaluation of the antidiarrheal activity of hydromethanol crude extracts of ruta chalepensis and vernonia amygdalina in mice," Evidence-Based Complementary and Alternative Medicine, vol. 2020, Article ID 8318713, 6 pages, 2020.

[29] W. T. Tadesse, "Experimental assessment of antidiarrheal and antisecretory activity of $80 \%$ methanolic leaf extract of Zehneria scabra in mice," BMC Complementary and Alternative Medicine, vol. 14, no. 1, p. 460, 2014.

[30] A. Rouf, M. Islam, and M. Rahman, "Evaluation of antidiarrhoeal activity Rumex maritimus root," Journal of Ethnopharmacology, vol. 84, no. 2-3, pp. 307-310, 2003.

[31] F. Awouters, C. J. E. Niemegeers, F. M. Lenaerts, and P. A. J. Janssen, "Delay of castor oil diarrhoea in rats: a new way to evaluate inhibitors of prostaglandin biosynthesis," Journal of Pharmacy and Pharmacology, vol. 30, no. 1, pp. 41-45, 1978.

[32] T. F. Belachew et al., "In Vivo evaluation of wound healing and anti-inflammatory activity of $80 \%$ methanol crude flower extract of Hagenia abyssinica (bruce) JF gmel in mice," Evidence-Based Complementary and Alternative Medicine, vol. 2020, Article ID 9645792, 12 pages, 2020.

[33] A. B. Awad, J. Toczek, and C. S. Fink, "Phytosterols decrease prostaglandin release in cultured P388D1/MAB macrophages," Prostaglandins, Leukotrienes and Essential Fatty Acids, vol. 70, no. 6, pp. 511-520, 2004.

[34] M. J. Bern, C. W. Sturbaum, S. S. Karayalcin, H. M. Berschneider, J. T. Wachsman, and D. W. Powell, "Immune system control of rat and rabbit colonic electrolyte transport. Role of prostaglandins and enteric nervous system," Journal of Clinical Investigation, vol. 83, no. 6, pp. 1810-1820, 1989.

[35] J. Galvez, A. Zarzuelo, M. E. Crespo et al., “Antidiarrhoeic activity ofSclerocarya birrea bark extract and its active tannin constituent in rats," Phytotherapy Research, vol. 5, no. 6, pp. 276-278, 1991.

[36] D. Zayede, T. Mulaw, and W. Kahaliw, "Antidiarrheal activity of hydromethanolic root extract and solvent fractions of clutia abyssinica jaub. \& spach.(euphorbiaceae) in mice," EvidenceBased Complementary and Alternative Medicine, vol. 2020, Article ID 5416749, 9 pages, 2020.

[37] M. Molla, Evaluation of The Anti-Diarrheal Activity of $80 \%$ Methanol Extract And Solvent Fractions of The Fruits of 
Mimusops Kummel A. DC.(Sapotaceae) in Mice, Addis Ababa University, Addis Ababa, Ethopia, 2016.

[38] M. Shaphiullah et al., "Antidiarrheal activity of the methanol extract of Ludwigia hyssopifolia Linn," Pakistan Journal of Pharmaceutical Sciences, vol. 16, no. 1, pp. 7-11, 2003.

[39] A. N. Agbon, H. O. Kwaneshie, and W. O. Hamman, "Antidiarrheal activity of aqueous fruit extract of Phoenix dactylifera (DATE PALM) in Wistar rats," British Journal of Pharmacology and Toxicology, vol. 4, no. 3, pp. 121-127, 2013.

[40] E. Tadesse et al., "Evaluation of the anti-diarrheal activity of the aqueous stem extract of Lantana camara Linn (Verbenaceae) in mice," BMC Complementary and Alternative Medicine, vol. 17, no. 1, p. 190, 2017.

[41] V. H. Begum, M. Dhanalakshmi, and P. Muthukumaran, "In vivo evaluation of antidiarrhoeal activity of the leaves of Azima tetracantha Linn," International Journal of Nutrition and Metabolism, vol. 5, no. 8, pp. 140-144, 2013.

[42] N. F. Pierce, C. C. J. Carpenter, H. L. Elliott, and W. B. Greenough, "Effects of prostaglandins, theophylline, and cholera exotoxin upon transmucosal water and electrolyte movement in the canine jejunum," Gastroenterology, vol. 60, no. 1, pp. 22-32, 1971.

[43] M. Hämäläinen, R. Nieminen, M. Asmawi, P. Vuorela, H. Vapaatalo, and E. Moilanen, "Effects of flavonoids on prostaglandin E2Production and on COX-2 and mPGES-1 expressions in activated macrophages," Planta Medica, vol. 77, no. 13, pp. 1504-1511, 2011.

[44] G. Viswanatha et al., "Antidiarrheal activity of alcoholic and aqueous extracts of stem bark of Thespesia populnea in rodents," Pharmacologyonline, vol. 3, pp. 222-230, 2007.

[45] R. S. Shiramane, "In-vivo antidiarrhoeal activity of ethanolic extract of Delonix regia flowers in experimental induced diarrhoea in wistar albino rats," International Journal of Research in Pharmacy and Chemistry, vol. 1, no. 3, pp. 2231-2781, 2011.

[46] M. Rahman, "Evaluation of antidiarrheal activity of methanolic extract of Maranta arundinacea Linn. leaves," Advances in Pharmacological Sciences, vol. 2015, Article ID 257057, 6 pages, 2015.

[47] T. S. Gaginella et al., "Actions of ricinoleic acid and structurally related fatty acids on the gastrointestinal tract. II. Effects on water and electrolyte absorption in vitro," Journal of Pharmacology and Experimental Therapeutics, vol. 195, no. 2, pp. 355-361, 1975. 